\title{
ANALISIS SEBARAN LOGAM BERAT PADA ALIRAN AIR DARI TEMPAT PEMBUANGAN AKHIR (TPA) SAMPAH AIR DINGIN
}

\author{
Fatmawinir $^{\mathrm{a}}$, Hamzar Suyani ${ }^{\mathrm{b}}$ dan Admin Alif ${ }^{\mathrm{b}}$ \\ ${ }^{a}$ Laboratorium Kopertis Wilayah X (Sumatera Barat, Riau, Jambi dan Kepulauan Riau) \\ ${ }^{\mathrm{b} J u r u s a n}$ Kimia, FMIPA Unand, Kampus Limau Manis, 25163 \\ Email : fatma.winir@yahoo.com
}

\begin{abstract}
Final Disposal of waste at Air Dingin Padang City using open dumping system is expected to negatively affect the groundwater and surrounding waterways. Research on the content of heavy metals in landfill water flow in the Air Dingin were made in 2 (two) times that were before the rain and after the rain, then the results were compared with the applicable standard. The content of heavy metals $\mathrm{Pb}, \mathrm{Cu}, \mathrm{Zn}, \mathrm{Cd}$ and $\mathrm{Mn}$ in Final Disposal (TPA) of waste at Air Dingin Padang City were $0.01-0.17 \mathrm{mg} / \mathrm{L}, \quad 0.005-0.025 \mathrm{mg} / \mathrm{L}, 0.0-0.7254 \mathrm{mg} / \mathrm{L}, 0.0-0.011 \mathrm{mg} / \mathrm{L}$, dan $0.0-$ $0.966 \mathrm{mg} / \mathrm{L}$. Pb concentration exceeded the quality standard KEPMEN LH 51 in 1995 leachate pond, while the flow of water and monitoring wells $\mathrm{Pb}$ metal content exceeds the quality standards PP.RI.No.82 on 2001 and Mn outlet river exceeds the quality standards PP.RI.No.82 on 2001. In population of all heavy metals well below the quality stanadard PP.RI.No.82 on 2001. The content heavy metals was affected by the distance of the location of waste, the $\mathrm{pH}$ value and after of the rain water around the landfill waste.
\end{abstract}

Keywords: Final Disposal (TPA) of waste, heavy metals.

\section{PENDAHULUAN}

Kota Padang merupakan kota yang pembangunannya meningkat setiap tahun. Peningkatan pada daerah perkotaan di kota Padang memicu meningkatnya aktifitas penduduk pada semua sektor baik perumahan, industri, perdagangan maupun sektor lainnya $^{[1]}$. Salah satu dampak dari aktifitas tersebut adalah limbah padat atau sampah. Sampah adalah limbah yang bersifat padat yang terdiri dari bahan organik maupun anorganik dari sisa atau residu yang timbul akibat aktifitas manusia yang dianggap tidak berguna lagi dan harus dikelola agar tidak membahayakan lingkungan dan melindungi investasi pembangunan ${ }^{[2]}$.

Fraksi anorganik dari sampah mengandung berbagai mineral, diantaranya logam-logam berat. Logam berat yang terdapat di dalam sampah akan terdekomposisi dan larut bersama terbentuknya lindi ${ }^{[3]}$. Semua hasil dekomposisi ini membentuk satu kesatuan dengan tanah. Air lindi mengalir di permukaan tanah masuk ke dalam kolam penampungan $^{[4]}$. Air lindi biasanya mengandung senyawa-senyawa organik (hidrokarbon, asam humat, tanah dan galat) dan anorganik (natrium, kalium, magnesium, fosfat, sulfat dan logam berat). Logam berat yang sering ditemukan dalam air lindi adalah arsen, besi, kadnium, kromium, merkuri, nikel, seng, tembaga dan timbal ${ }^{[5]}$. Logamlogam tersebut diketahui dapat mengumpul dan tinggal di dalam tubuh suatu organisme dalam jangka waktu lama sebagai racun yang terakumulasi ${ }^{[6]}$. Pendapat yang sama juga dikatakan oleh Palar bahwa apabila jumlah dari logam berat masuk ke dalam tubuh manusia dengan jumlah berlebih, maka akan berubah fungsi menjadi racun bagi tubuh ${ }^{[7]}$. 


\section{METODOLOGI PENELITIAN}

\section{Bahan Kimia, Peralatan Dan Instrumentasi}

Bahan-bahan yang digunakan pada penelitian ini adalah asam nitrat $\left(\mathrm{HNO}_{3}\right)$ pekat, akuades dan sampel diambil dari 7 (tujuh) titik pada aliran air dari TPA sampah Air Dingin kota Padang.

Alat-alat yang digunakan dalam penelitian ini adalah Spektrofotometer Serapan Atom (SSA) shimadzu AA-6300, termometer, pemanas listrik, alat-alat gelas dan seperangkat alat saring vakum.

\section{Prosedur Penelitian}

\section{Persiapan Sampel}

Pengambilan sampel pada aliran air dari TPA sampah Air Dingin kota Padang diambil pada 7 (tujuh) lokasi. Lokasi tersebut yaitu: kolam lindi 1 (sampel A), kolam lindi 3 (sampel B), kolam lindi 7 (sampel C), outlet ke sungai (sampel D), jarak 50 meter dari outlet sungai (sampel E), sumur pantau III (sampel F) dan sumur penduduk jarak 300 meter (sampel G). Sampel-sampel tersebut dimasukkan dalam wadah tertutup dengan diberi kode masingmasingnya. Sampel disaring dengan alat saring vakum, kemudian sampel yang telah disaring dipipet $50 \mathrm{~mL}$ dan dimasukan ke dalam gelas piala $100 \mathrm{ml}$. Pengolahan sampel dilakukan dengan destruksi basah asam nitrat. Sampel ditambahkan $5 \mathrm{~mL} \mathrm{HNO}_{3}$ pekat, panaskan dengan hot plate terus menerus sampai sisa volumenya $15-20 \mathrm{~mL}$ dengan suhu $200^{\circ} \mathrm{C}$. Wadah sampel ditutup dengan kaca arloji selama destruksi. Pada saat destruksi sampel dijaga jangan sampai kering kemudian lakukan juga destruksi untuk blanko. Pindahkan larutan hasil destruksi ke dalam labu ukur $50 \mathrm{~mL}$ kemudian ditambahkan akuades sampai tanda batas dan dicampur hingga homogen. Larutan siap dianalisis dengan Spektrofotometer Serapan Atom (SSA).

\section{Pengambilan Sampel Air Sumur}

Sampel air sumur gali penduduk, diambil pada jarak 300 meter dengan ketingian 78 meter dari TPA, sampel air dimasukan ke dalam jerigen. Setelah itu, setiap dirigen diberi kode masing-masingnya. Sampel siap untuk di destruksi dan dianalisis.

\section{Pengambilan Sampel Air Kolam Lindi}

Pengambilan sampel air kolam lindi diambil dengan 3 (tiga) titik yaitu kolam Lindi 1, kolam Lindi 3 dan kolam Lindi 7, kemudian sampel dimasukan ke dalam jerigen. Setelah itu, setiap jerigen diberi kode masing-masing. Sampel siap untuk didestruksi dan dianalisis.

\section{Pengambilan Sampel Air Sungai}

Pengambilan sampel aliran ke sungai (Outlet ke Sungai) dan jarak 50 meter dari outlet sungai diambil sampel air kemudian dimasukan ke dalam jerigen. Setelah itu, setiap jerigen diberi kode masing-masingnya. Sampel siap untuk didestruksi dan dianalisis.

\section{Pengambilan Sampel Untuk Analisis Sifat Fisik dan Kimia}

Cara pengambilan sampel air untuk analisis sifat fisik dan kimia dilakukan dengan proses yang sama yaitu dengan menurunkan timba ke dalam sumur, kemudian airnya dicampur dalam satu jerigen untuk mengetahui tingkat rata-rata kualitas airnya. Analisis sampel air dilakukan untuk parameter air yang tidak bisa diawetkan ( $\mathrm{pH}$, suhu, warna, bau), dan dianalisis di laboratorium untuk parameter yang dapat diawetkan.

Pengukuran Sampel dengan
Spektrofotometer Serapan Atom (SSA)
Pengukuran logam berat dilakukan dengan
penambahan asam nitrat pekat yang
dipanaskan sampai larut menjadi bening
kemudian ditambah lagi dengan akuades
dengan menggunakan Spektrofotometri
Serapan Atom (SSA).

\section{HASIL DAN PEMBAHASAN}

Warna dan bau sampel air kolam lindi sampah TPA Air Dingin menunjukan tidak memenuhi syarat (Tabel 1). Warnanya kuning kecoklatan yang seharusnya tidak bewarna baunya juga sangat menyengat. Timbulnya bau air kolam lindi tersebut hasil dari proses perombakan atau dekomposisi bahan organik, khususnya perombakan komponen-komponen secara anaerobik akan menghasilkan senyawa yang berbau anyir dan berbau busuk yang disebabkan oleh senyawa amoniak, $\mathrm{H}_{2} \mathrm{~S}$ dan methan ${ }^{[8]}$. 
Dari hasil pengamatan terhadap sampel air sumur pantau (sampel F) maka warna dan bau tidak memenuhi syarat karena agak berwarna dan berbau. Untuk sampel air sumur penduduk sebagai sumur kontrol semuanya sudah memenuhi syarat yaitu tidak bewarna dan tidak berbau, karena lokasi sumur jauh dan ketinggian dari TPA. Warna dan bau pada air sumur pantau disebabkan karena rembesan dari air lindi sampah TPA Air Dingin, hasil dari perombakan dekomposisi bahan organik $^{[9]}$.

Pencemaran air lindi sampah akibat air hujan mencuci sampah yang sudah busuk serta segala kotoran yang terperangkap di dalammnya. Bau yang timbul pada air sumur pantau adalah akibat adanya hasil perombakan sampah yang menghasilkan $\mathrm{H}_{2} \mathrm{~S}$ yang berbau busuk, dan dapat meresap ke air sumur bersama-sama dengan air hujan.

\section{Nilai pH dan suhu sampel air TPA}

Tanah di TPA Air Dingin adalah tanah aluvial yang memiliki nilai $\mathrm{pH}$ rendah dan kejenuhan basa rendah. ${ }^{[10]}$ Pada $\mathrm{pH}$ asam, logam berat mudah larut dalam air tanah, sehingga konsentrasi logam dalam air tanah dapat meningkat. Nilai $\mathrm{pH}$ pada sumur penduduk yaitu 6,87 memenuhi baku mutu Peraturan Pemerintah No.82 Tahun 2001 yaitu berkisar antara $\mathrm{pH}$ 6-9, $\mathrm{pH}$ sumur pantau (sampel F) yaitu 5,87 sedangkan $\mathrm{pH}$ kolam lindi bersifat basa, yaitu berkisar antara 8,13-8,24. Berdasarkan Peraturan Pemerintah No.82 Tahun 2001 baku mutu air sumur, nilai $\mathrm{pH}$ di semua titik tidak memenuhi baku mutu kecuali pada sumur penduduk.
Jika dilihat dari nilai $\mathrm{pH}$ kolam lindi dan air sumur penduduk maka nilai $\mathrm{pH}$ air tanah di kawasan TPA Air Dingin lebih dipengaruhi oleh kondisi alamiah air tanah, dimana karakteristik tanah aluvial memiliki $\mathrm{pH}$ tanah rendah, sehingga $\mathrm{pH}$ air tanah bersifat asam. Hal ini juga dikemukakan pada penelitian Zulfahmi, dimana nilai $\mathrm{pH}$ pada sumur yang letaknya tak jauh dari TPA sampah Air Dingin dalam kondisi asam yang berkisar antara 4,95-5,98. Temperatur air sumur pantau pada penelitian ini $27^{\circ} \mathrm{C}$ lebih rendah dibandingkan temperatur kolam lindi $28^{\circ} \mathrm{C}$ dan temperature sumur penduduk $26,5^{\circ} \mathrm{C}$. Temperatur dikawasan TPA Air Dingin berdasarkan Permenkes No.416 dan PP.RI.No.82 tahun 2001 masih memenuhi baku mutu. Berdasarkan baku mutu air kelas I (PP No 82 Tahun 2001), suhu rata-rata air sumur masih berada pada kisaran suhu maksimum yang diperbolehkan $\left(26-2^{\circ} \mathrm{C}\right)$ dan tergolong suhu air normal, sehingga dari parameter ini tidak terlihat adanya indikasi pencemaran air.

Dari Tabel 2 terlihat bahwa jarak lindi terhadap air tanah dangkal tidak mempengaruhi temperatur. Nilai temperatur lebih dipengaruhi oleh waktu pengambilan sampel dan keadaan sumur. Perbedaan temperatur pada masing-masing sumur tidak terlalu signifikan. Pada sumur yang terbuka, temperatur cenderung tinggi yaitu $28,5^{\circ} \mathrm{C}$. Suhu limbah yang berasal dari kolam lindi umumnya lebih tinggi dibandingkan dengan air penerima.

Tabel 1. Kualitas warna dan bau sampel air dari TPA sampah Air Dingin Kota Padang

\begin{tabular}{lll}
\hline No. & Sampel & Hasil penelitian warna/ bau \\
\hline 1 & Sampel A & Hitam/ sangat menyengat \\
2 & Sampel B & Merah kehitaman/ menyengat \\
3 & Sampel C & Merah kehijauan/ sedikit menyengat \\
4 & Sampel D & Kukuningan / kurang menyengat \\
5 & Sampel E & Sedikit bening / agak berbau \\
6 & Sampel F & Sedikit bening/ agak berbau \\
7 & Sampel G & Bening / tidak berbau \\
\hline
\end{tabular}


Tabel 2. Nilai pH dan temperatur sampel air dari TPA sampah Air Dingin Kota Padang

\begin{tabular}{cccc}
\hline No. & Sampel & $\mathbf{p H}$ & Temperatur $\left({ }^{\circ} \mathbf{C}\right)$ \\
\hline 1 & Sampel A & 8,13 & 28 \\
2 & Sampel B & 8,22 & 28 \\
3 & Sampel C & 8,24 & 28 \\
4 & Sampel D & 7,96 & 27 \\
5 & Sampel E & 7,38 & 27 \\
6 & Sampel F & 5,87 & 27 \\
7 & Sampel G & 6,87 & 26,5 \\
\hline
\end{tabular}

\section{Hasil pengukuran sampel dengan Spektrofotometri Serapan Atom (SSA)}

Pengukuran sampel dilakukan pada 2 (dua) waktu yaitu sebelum hujan dan sesudah hujan. Pada 2 (dua) waktu tersebut terdapat kandungan logam berat yang berbeda yaitu pada waktu sesudah hujan lebih tinggi dibandingkan dengan waktu sebelum hujan, hal yang sama juga dilakukan oleh Marzieh, 2010.

\section{Logam Timbal (Pb)}

Konsentrasi logam timbal $(\mathrm{Pb})$ di kolam lindi adalah $0,17 \mathrm{mg} / \mathrm{L}$, kandungan logam timbal $(\mathrm{Pb})$ pada sumur penduduk yaitu $0,02 \mathrm{mg} / \mathrm{L}$ dan pada sumur pantau $0,17 \mathrm{mg} / \mathrm{L}$. Kadar logam berat pada kolam lindi, sumur pantau dan aliran air rata-rata telah melampaui baku mutu Kepmen LH No. 51 Tahun 1995 adalah $0,1 \mathrm{mg} / \mathrm{L}$. Tingginya kadar logam timbal $(\mathrm{Pb})$ pada kolam lindi dan sumur pantau yang terletak (jaraknya 1-50 meter) disebabkan karena akumulasi dari hasil dekomposisi sampah organik dan anorganik yang ditimbun di TPA Air Dingin, disebabkan oleh bahan anorganik berupa ionion. Penelitian Candrianto (2001) juga memperlihatkan bahwa logam $\mathrm{Pb}$ ditemukan dengan konsentrasi yang berkisar antara $0-0,27 \mathrm{mg} / \mathrm{L}$.

Dari Tabel 3 dapat dilihat bahwa kosentrasi logam timbal $(\mathrm{Pb})$ pada kolam lindi dan sumur pantau diatas baku mutu, karena adanya pengaruh rembesan air lindi sampah dari TPA. Hal ini dibuktikan dengan semakin jauh jarak lokasi sampel dengan TPA maka nilainya semakin menurun. Hal ini juga diperlihatkan pada hasil pengukuran sumur penduduk (jarak 300-500 meter) dimana hasil yang didapat di bawah baku mutu $0,03 \mathrm{mg} / \mathrm{L}$ menurut PP RI. No. 82 Tahun 2001. Selain itu, kebanyakan timbal yang terlepas ke lingkungan tersimpan di tanah. Selain itu juga keberadaan timbal juga dipengaruhi oleh masuknya sampah baru sehingga akan menyebabkan perubahan $\mathrm{pH}$ terjadinya presipitasi, pengenceran, oksidasi atau reduksi, sorpsi, pertukaran ion serta reaksi dengan zat-zat organik.

\section{Logam Tembaga (Cu)}

Pada sumur penduduk di kawasan TPA konsentrasi logam berat tembaga $(\mathrm{Cu})$ berkisar antara antara $0,005-0,007 \mathrm{mg} / \mathrm{L}$ di kolam lindi terdeteksi adanya tembaga $(\mathrm{Cu})$ berkisar antara 0,012-0,025 mg/L (Tabel 4). Berdasarkan Peraturan Pemerintah No.82 Tahun 2001, kadar maksimum yang diperbolehkan adalah $0,02 \mathrm{mg} / \mathrm{L}$, maka kandungan tembaga $(\mathrm{Cu})$ pada sumur penduduk masih memenuhi baku mutu. Terdeteksinya tembaga pada kolam lindi diperkirakan karena terjadinya endapan logam tembaga pada $\mathrm{pH}$ kolam lindi 8,13 .

Tabel 3. Hasil analisis logam timbal $(\mathrm{Pb})$ dikawasan TPA

\begin{tabular}{cccc}
\hline No. & $\begin{array}{c}\text { Jenis } \\
\text { Sampel }\end{array}$ & \multicolumn{2}{c}{$\begin{array}{c}\text { Kosentrasi Pb } \\
(\mathbf{m g} / \mathbf{L})\end{array}$} \\
\cline { 3 - 4 } & & $\begin{array}{c}\text { Sebelum } \\
\text { Hujan }\end{array}$ & $\begin{array}{c}\text { Sesuda } \\
\text { h Hujan }\end{array}$ \\
\hline & & 0,11 & 0,15 \\
1 & Sampel A & 0,07 & 0,1 \\
2 & Sampel B & 0,07 \\
3 & Sampel C & 0,1 & 0,17 \\
4 & Sampel D & 0,13 & 0,15 \\
5 & Sampel E & 0,1 & 0,12 \\
6 & Sampel F & 0,15 & 0,17 \\
7 & Sampel G & 0,01 & 0,02 \\
\hline
\end{tabular}


Tabel 4. Hasil analisis logam tembaga $(\mathrm{Cu})$ dikawasan TPA

\begin{tabular}{cccc}
\hline & & \multicolumn{2}{c}{$\begin{array}{c}\text { Kosentrasi Cu } \\
\text { (mg/L) }\end{array}$} \\
\cline { 3 - 4 } No. & $\begin{array}{c}\text { Jenis } \\
\text { Sampel }\end{array}$ & $\begin{array}{c}\text { Sebelum } \\
\text { Hujan }\end{array}$ & $\begin{array}{c}\text { Sesudah } \\
\text { Hujan }\end{array}$ \\
\hline 1 & Sampel A & 0,018 & 0,022 \\
2 & Sampel B & 0,016 & 0,025 \\
3 & Sampel C & 0,013 & 0,012 \\
4 & Sampel D & 0,013 & 0,009 \\
5 & Sampel E & 0,006 & 0,008 \\
6 & Sampel F & 0,009 & 0,008 \\
7 & Sampel G & 0,005 & 0,007 \\
\hline
\end{tabular}

Konsentrasi tembaga pada kolam lindi dipengaruhi oleh garam-garam tembaga, misalnya; tembaga karbonat $\left(\mathrm{CuCO}_{3}\right)$, tembaga hidroksida $\mathrm{Cu}(\mathrm{OH})_{2}$, dan tembaga sulfida $(\mathrm{CuS})$ bersifat tidak mudah larut dalam air ${ }^{[11]}$. Jarak lindi terhadap kandungan $\mathrm{Cu}$ sumur penduduk dapat mempengaruhi.

\section{Logam Seng (Zn)}

Konsentrasi logam berat seng di kolam lindi berkisar antara $0,0-0,7254 \mathrm{mg} / \mathrm{L}$. Secara keseluruhan konsentrasi logam berat seng (Zn) pada kolam lindi, outlet ke sungai, 50 meter dari outlet sungai, sumur pantau dan sumur penduduk dapat dilihat pada Tabel 5 . Pada sampel B tidak terdeteksi adanya logam seng (Zn) tingkat kelarutan seng pada sampel $\mathrm{B}$ rendah, dimana $\mathrm{pH}$ kolam lindi pada sampel B adalah 8,22. Pada $\mathrm{pH}$ 6-12 seng akan sedikit larut dalam air, dengan demikian seng akan mengendap pada kolam.

Tabel 5. Hasil analisis logam seng (Zn) di kawasan TPA

\begin{tabular}{ccccr}
\hline & & \multicolumn{2}{c}{$\begin{array}{c}\text { Kosentrasi Zn } \\
\text { Nonis }\end{array}$} & \multicolumn{2}{c}{ (mg/L) } & Sep \\
\cline { 3 - 4 } No. & $\begin{array}{c}\text { Sampel } \\
\text { Samelum } \\
\end{array}$ & $\begin{array}{c}\text { Sesudah } \\
\text { Hujan }\end{array}$ & $\begin{array}{c}\text { Hujan } \\
\text { pad }\end{array}$ \\
\cline { 1 - 3 } 1 & Sampel A & 0,0093 & 0,7254 & a \\
2 & Sampel B & ttd & 0,0129 & umu \\
3 & Sampel C & 0,0400 & 0,6791 & mny \\
4 & Sampel D & 0,0210 & 0,0559 & a \\
5 & Sampel E & ttd & ttd & loga \\
6 & Sampel F & ttd & ttd & m, \\
7 & Sampel G & ttd & ttd & kon \\
& & & & sent
\end{tabular}

rasi seng dipengaruhi oleh nilai $\mathrm{pH}$, dimana nilai $\mathrm{pH}$ di sampel $\mathrm{F}$ adalah 5,87. Di kawasan sumur dangkal lainnya dengan $\mathrm{pH}$ sedikit asam yang bervariasi begitu juga halnya dengan sumur penduduk yang mempunyai $\mathrm{pH}$ 6,87, maka nilai konsentrasi seng ( $\mathrm{Zn})$ pun bervariasi meskipun dengan kelarutan yang rendah. Pada $\mathrm{pH}$ 6-12, seng membentuk $\mathrm{ZnCO}_{3}$ dan $\mathrm{Zn}(\mathrm{OH})_{2}$ yang dapat mengontrol tingkat kelarutan seng. ${ }^{[12]}$

Pada $\mathrm{pH}$ asam atau netral $(\mathrm{pH}$ 6-13) seng dapat larut. Selain itu, Ion seng mudah terserap ke dalam sedimen dan tanah. ${ }^{[12]}$ Semakin jauh jarak sumur dangkal terhadap lindi semakin rendah konsentrasi logam berat. Selain itu nilai $\mathrm{pH}$ air tanah dan adanya sumber sampah yang masuk dekat sumur akan mempengaruhi konsentrasi logam berat. Kandungan logam berat dalam sumur tergantung dari karakteristik masing-masing, dimana logam tersebut dapat mengalami presipitasi, pengenceran, oksidasi atau reduksi, sorpi, pertukaran ion serta kandungan zat organik.

\section{Logam Kadmium (Cd)}

Kandungan kadmium (Cd) pada sumur pantau berkisar $0,011 \mathrm{mg} / \mathrm{L}$ sedangkan pada kolam lindi $0,004 \mathrm{mg} / \mathrm{L}$. Kandungan logam kadmium (Cd) sedikit dibandingkan logam lainnya. Hal itu karena kualitas air sumur juga dipengaruhi secara langsung ataupun tidak langsung oleh proses mikrobiologi, yang mentransformasikan zat-zat anorganik dan organik dalam air. Matthess (1982) menggunakan material terlarut atau yang tersuspensi dalam air untuk proses metabolismenya, dan kemudian mereka melepas kembali produk metaboliknya ke dalam air. Pada Tabel 6 dapat dilihat sampel $\mathrm{B}$ dan $\mathrm{C}$ tidak terdeteksi adanya $\mathrm{Cd}$ karena $\mathrm{pH}$ lindi termasuk basa yaitu 8,2 .

Kandungan logam berat kadmium (Cd) akan meningkat pada lindi saat mengalami fase asam, dimana $\mathrm{pH}$ rendah sehingga logam terlarut. Sebaliknya kandungan logam akan turun pada saat fase fermentasi dan maturasi, dimana nilai $\mathrm{pH}$ meningkat atau mencapai netral. Pencemaran air tanah dapat berasal dari sampah-sampah industri, dengan indikator meningkatnya kadar logam berat kadmium $(\mathrm{Cd})$ di dalam air. Unsur tersebut termasuk unsur hara mikro, yang dibutuhkan oleh manusia atau organisme air dalam jumlah sangat sedikit $(<0,05 \mathrm{mg} / \mathrm{L})$, dan bila 
melebihi kadar tersebut merupakan racun yang sangat berbahaya, dapat menyerang ikatan-ikatan belerang dalam enzim, sehingga enzim-enzim tersebut bersifat terikat dan tidak aktif.

\section{Logam Mangan (Mn)}

Konsentrasi mangan pada kolam lindi sangat tinggi terdeteksi, sedangkan kandungan logam mangan di sumur pantau dan sumur penduduk yang berada di kawasan TPA tidak terdeteksi. Hasil analisis konsentrasi mangan pada sampel air outlet ke sungai berkisar antara 0,153-0,966 mg/L disebabkan karena rembesan air sampah dari TPA bergerak mengikuti aliran air kesungai. Nilai tersebut menunjukkan bahwa air sungai tidak layak untuk dikonsumsi jika dibandingkan dengan Peraturan Pemerintah Nomor 82 Tahun 2001 tentang pengelolaan kualitas air dan pengendalian pencemaran air sebesar 0,1 $\mathrm{mg} / \mathrm{L}$.

Hasil analisis pada Tabel 7 rata-rata kosentrasi mangan pada sampel air kolam lindi berkisar antara 0,317-0,573 $\mathrm{mg} / \mathrm{L}$. Konsentrasi mangan yang tinggi sangat berbahaya bagi manusia karena dapat menimbulkan keracunan kronis yang banyak terdapat pada gandum dan buah-buahan. Adanya aktifitas penggalian lapisan tanah di TPA diduga menyebabkan terangkatnya mangan ke permukaan dan kemudian mengalir bersama air lindi ke kolam lindi dan menuju sungai.

Tabel 6. Hasil analisis logam kadmium (Cd) dikawasan TPA

\begin{tabular}{cccc}
\hline & \multirow{2}{*}{ Jenis } & \multicolumn{2}{c}{$\begin{array}{c}\text { Kosentrasi Cd } \\
(\mathbf{m g} / \mathbf{L})\end{array}$} \\
\cline { 3 - 4 } No. & Sampel & $\begin{array}{c}\text { Sebelum } \\
\text { Hujan }\end{array}$ & $\begin{array}{c}\text { Sesudah } \\
\text { Hujan }\end{array}$ \\
\hline 1 & Sampel A & 0,002 & 0,004 \\
2 & Sampel B & 0,005 & ttd \\
3 & Sampel C & ttd & 0,002 \\
4 & Sampel D & 0,006 & 0,003 \\
5 & Sampel E & 0,002 & 0,010 \\
6 & Sampel F & 0,006 & 0,011 \\
7 & Sampel G & 0,003 & 0,009 \\
\hline
\end{tabular}

Tabel 7. Hasil analisis logam mangan (Mn) dikawasan TPA

\begin{tabular}{cccc}
\hline No. & $\begin{array}{c}\text { Jenis } \\
\text { Sampel }\end{array}$ & \multicolumn{2}{c}{$\begin{array}{c}\text { Kosentrasi Mn } \\
(\mathbf{m g} / \mathbf{L})\end{array}$} \\
\cline { 3 - 4 } & & $\begin{array}{c}\text { Sebelum } \\
\text { Hujan }\end{array}$ & $\begin{array}{c}\text { Sesudah } \\
\text { Hujan }\end{array}$ \\
\hline 1 & Sampel A & 0,095 & 0,573 \\
2 & Sampel B & 0,246 & 0,503 \\
3 & Sampel C & 0,157 & 0,317 \\
4 & Sampel D & 0,153 & 0,966 \\
5 & Sampel E & ttd & ttd \\
6 & Sampel F & ttd & ttd \\
7 & Sampel G & ttd & ttd \\
\hline
\end{tabular}

Pada air permukaan mangan berada pada bentuk terlarut dan tersuspensi tergantung pada faktor seperti $\mathrm{pH}$, keberadaan ion dan potensial reduksi oksidasi. Pada konsentrasi melebihi $0,1 \mathrm{mg} / \mathrm{L}$ ion mangan menyebabkan rasa yang tidak diinginkan pada air minum dan menimbulkan noda pada pipa ledeng dan pakaian. ${ }^{[14]}$ Tumbuhan yang membusuk dan bangkai hewan menyumbangkan secara nyata sedikit logam ke atas air permukaan dan dasar endapan.

\section{Kualitas Air tanah dangkal (Sumur Penduduk)}

Hasil pengukuran logam berat pada sumur penduduk dengan jarak 300-500 meter dari TPA dibawah baku mutu menurut PP No. 82 tahun 2001. Hal ini menunjukkan adanya hubungan jarak lokasi sumur dengan TPA maka kadar logam berat dalam air sumur semakin kecil. Hal ini dari hasil penelitian Komala (2008) terhadap kandungan logam berat pada sumur disekitar TPA yang berada pada jarak 98-300 meter tidak memenuhi baku mutu.

\section{KESIMPULAN}

Dari penelitian yang telah dilakukan diperoleh kesimpulan bahwa konsentrasi logam berat $\mathrm{Pb}, \mathrm{Cu}, \mathrm{Zn}, \mathrm{Cd}$ dan $\mathrm{Mn}$ di kawasan TPA Air Dingin ini berkisar 0,01$0,17 \mathrm{mg} / \mathrm{L}, 0,005-0,025 \mathrm{mg} / \mathrm{L}, 0,0-0,7254$ $\mathrm{mg} / \mathrm{L} ; 0,0-0,011 \mathrm{mg} / \mathrm{L}$, dan $0,0-0,966 \mathrm{mg} / \mathrm{L}$. Konsentrasi $\mathrm{Pb}$ melebihi bakumutu Kepmen LH No.51 tahun 1995 di kolam lindi, sedangkan pada aliran air dan sumur pantau kandungan logam $\mathrm{Pb}$ juga melebihi baku mutu PP.RI.No.82 tahun 2001 dan logam Mn outlet ke sungai melebihi baku mutu 
PP.RI.No.82 tahun 2001. Pada sumur penduduk semua logam berat $\mathrm{Pb}, \mathrm{Cu}, \mathrm{Zn}, \mathrm{Cd}$ dan Mn di bawah baku mutu PP.RI.No.82 tahun 2001. Bila dibandingkan terhadap pengambilan sampel pada 2 (dua) waktu yaitu sebelum dan sesudah hujan maka didapatkan konsentrasi logam berat lebih tinggi sesudah hujan.

\section{DAFTAR PUSTAKA}

1. Azkha, N. Analisis Timbulan. Komposisi dan Karakteristik Sampah di Kota Padang. Jurnal Kesehatan Masyarakat. 1 (2006) 14-18.

2. Badan Standardisasi Nasional. SNI 192454-2002, Tata Cara Pengelolaan Teknis Sampah Perkotaan, Jakarta, 2002.

3. Veronika, E. Evaluasi Saluran Pengumpul dan pengaruh Lindi Terhadap Lingkungan Sekitar TPA keputih. Jurnal Lingkungan. 3 (2007) 1-3

4. Azmir. Pengaruh Air Lindi Tempat Pembuangan Akhir Sampah Terhadap Kualitas Air Tambak Ikan di Kelurahan Terjun Kecamatan Medan Merdeka. Jurnal Kesehatan Masyarakat, 2 (2010) 12-15.

5. Suin, M. Nurdin. Dampak Pencemaran pada Ekosistem Pengairan Proseding Penataran Pencemaran Lingkungan Dampak dan Penanggulangannya. Pemda TK II. Padang. (1994)
6. Fardiaz. S, 1992, Polusi Air dan Udara, Karnisius, Yogyakarta.

7. Palar, H, 2004, Pencemaran dan toksikologi logam berat, Rineka Cipta, Jakarta.

8. Marzieh, S. Variation in soil heavy metal concentrations around and downstream of a municipal waste landfill. World Congress of Soil Science, Soil Solutions for a Changing World. 4 (2010) 1-6.

9. Candrianto, Analisis Beberapa Logam Berat Pada Air Sumur Penduduk di TPA Air Dingin Padang, Padang, 2001.

10. Pusat Penelitian Tanah, Peta Tanah Tinjau Sumatera Barat I (Kota Padang, Kab. Padang Pariaman, dan Kab. Agam), Padang, 1984.

11. Effendi, H. Telah Kualitas Air Bagi Pengelolaan Sumber Daya dan Lingkungan Perairan, Kanisius. Yokyakarta, 2003.

12. Vogel. Terjemahan Setiono dan Pudjaatmaka, Analisis Anorganik Kualitatif Makro dan Semi Mikro, PT Kalman Media Pusaka 205-294. Jakarta, 1985.

13. Matthess, G, The Properties of Groundwater. John Wiley and Sons. New York, 1982.

14. Perpamsi (persatuan perusahaan air minum seluruh indonesia). 2003. Indonesia.

15. Komala, P.S. Pengaruh Sistem Open Dumping di Lokasi Pembuangan Akhir Terhadap kandungan Logam Berat Pada Air Tanah Dangkal dan Sekitarnya (LPA Air Dingin Padang). Jurnal teknik Lingkungan. 1 (2008) 1-8. 